Buana Sains Vol 18 No 1: 85 - 96, 2018

\title{
APLIKASI TEKNOLOGI Dielectric Barrier Discharge-UV Plasma TERHADAP SIFAT FISIK DAN KIMIA TELUR AYAM (Gallus gallus domesticus)
}

\author{
Endrika Widyastuti dan Aldilah Daydeva \\ Jurusan Teknologi Hasil Pertanian, Fakultas Teknologi Pertanian ,Universitas Brawijaya
}

\begin{abstract}
Eggs are food that contains high nutrition, however egg products susceptible damage so preservation process is required. Dielectric Barrier Discharge (DBD) UV Plasma has proven very effective as an alternative technology for preserve fresh egg by inactivation bacteria and prevent contamination in fresh egg. Aim of this study is to evaluated effect of Dielectric Barrier Discharge (DBD) UV Plasma on physical and chemical quality of chicken eggs (Gallus gallus domesticus). The fresh eggs were stored at room temperature and assessed for their Physical (Haugh unit and yolk index) and chemical properties (yolk $\mathrm{pH}$, albumen $\mathrm{pH}$, and egg nutrition) on $0,5,7,11$, and 14 days. Analysis of variance (ANOVA) was used to analyse significant difference among the samples. The result shows that DBD UV plasma can maintain haugh unit, yolk index, yolk $\mathrm{pH}$, and albumen $\mathrm{pH}$ than control. The eggs treated with DBD UV recorded have no significant difference for egg nutrition.
\end{abstract}

Keywords: Chicken Egg (Gallus gallus domesticus); DBD UV Plasma; nutrition; physical; chemical quality

\section{Pendahuluan}

Telur ayam (Gallus gallus domesticus) merupakan bahan pangan yang mengandung nilai gizi tinggi, mudah diolah dan harganya relatif murah jika dibandingan dengan sumber protein hewani lainnya (Litbang Pertanian, 2010). Produksi telur ayam Indonesia meningkat rata-rata $3.29 \%$ per tahun, dimana permintaan konsumsi nasional akan meningkat $4.78 \%$ per tahunnya (Nuryati et al., 2015). Disisi lain telur ayam (Gallus gallus domesticus) mudah mengalami kerusakan secara fisik (Muchtadi et al., 2010), kimia (Haryoto, 2010) dan mikrobiologis (Saraswati, 2012) sehingga dapat menurunkan masa simpan telur segar. Kerusakan yang paling banyak terjadi adalah kerusakan secara mikrobiologis. Beberapa kasus keracunan mikrobiologis akibat Salmonella sp. dan E. coli pada telur cukup tinggi di Indonesia (Kalfat et al., 2015).

Berbagai cara dilakukan agar kualitas telur segar dapat dipertahankan dalam waktu yang lebih lama. Prinsip dalam pengawetan telur segar adalah mencegah penguapan air dan terlepasnya gas-gas lain dari didalam telur selama masa penyimpanan (Warintek, 2016). Beberapa alternatif pengawetan telur segar diantaranya teknologi pasteurisasi (Koswara, 2009), Extremely Low Frequency Magnetic Fields (ELF-MF) (Sudarti, 2016), dan berbasis Thyme Oil dan Cold Nitrogen Plasma (CNP) (Cui et al., 2016). Akan tetapi teknologi-teknologi tersebut mempunyai kelemahan diantaranya masih menggunakan suhu yang tinggi, dan waktu yang lama, serta penanganan yang tepat (Widyastuti et al., 2017). 
Inovasi teknologi pengawetan telur terbaru yang dapat meminimalisir kekurangan teknologi sebelumnya yaitu menggunakan DBD Plasma (Wan et al., 2017) dan DBD UV Plasma (Anggraeni et al., 2017). DBD UV plasma yaitu suatu teknologi yang menggabungkan teknologi plasma dan sinar ultraviolet. DBD UV plasma ini memanfaatkan lempengan elektroda aluminium, akrilik (lapisan dielektrik) serta lampu UV yang diletakkan pada bagian dalam ruang plasma alat dan memungkinkan plasma melakukan kontak dengan elektroda sehingga dapat menghasilkan lucutan elektron yang dapat mengionisasi gas di dalam ruang alat sterilisasi, serta sinar UV yang digunakan untuk mensterilisasi ruang plasma dan mampu mencegah dekontaminasi mikroorganisme (Nur, 2011; Morgan, 2009). Kemudian, gas terionisasi ini akan bereaksi dengan membran sel dari bakteri Salmonella sp. sehingga mengakibatkan pecahnya membran atau lisis dan isi sel dari bakteri keluar kemudian mati (Nur, 2011). Aplikasi DBD UV plasma sendiri dapat diaplikasikan pada ikan kembung dimana selama penyimpanan 12 hari menunjukkan dapat menjaga kualitas asam amino (Teke, 2014), pada cabai merah kualitas fisiknya masih tetap terjaga dibandingkan dengan yang tidak diberi perlakuan (Pratama, 2016), serta selama penyimpanan pada beras teknologi ini aman untuk digunakan (Rijal, 2015). Penggunaan DBD UV plasma pada telur dapat menurunkan hingga $6 \log \mathrm{CFU} / \mathrm{ml}$ (Anggraeni et al., 2017). Tujuan dari penelitian ini adalah mengetahui Aplikasi Teknologi Dielectric Barrier Discharge-UV Plasma terhadap Sifat Fisik dan Kimia Telur Ayam (Gallus gallus domesticus).

\section{Metode Penelitian}

Bahan yang digunakan pada penelitian ini adalah telur ayam (Gallus gallus domesticus) dengan berat $\pm 60 \mathrm{~g}$ dan umur simpan 0 hari yang diambil dari peternakan telur di Desa Tlekung Kota Batu, alkohol $70 \%$, dan aquades $\mathrm{pH} 7$. Alat yang digunakan meliputi DBD UV Plasma, timbangan analitik (Mattler Toledo), pipet, $\mathrm{pH}$ meter (Hanna), egg tray, spatula, dan glassware (Pyrex).

\section{Persiapan telur ayam segar} dilakukan sesuai metode Anggraeni et al. (2017) yang dimodifikasi. Telur ayam dengan berat $\pm 60 \mathrm{~g}$ dicuci dibawah air mengalir, kemudian dikeringkan pada suhu ruang selama beberapa menit. Selanjutya telur diletakkan pada egg trayer dan disimpan pada suhu ruang. Alat DBD Plasma diaplikasikan pada sampel telur ayam ras. Pada tahap ini, juga digunakan sampel telur ayam tanpa perlakuan (a) dan telur ayam dengan perlakuan (b), sehingga terdapat dua sampel telur ayam ras. Kedua sampel tersebut kemudian disimpan selama 14 hari.

Proses Sterilisasi telur segar DBD UV Plasma (Widyastuti et al., 2017) dilakukan melalui tahapan pembersihan seluruh komponen terlebih dahulu dengan menggunakan tisu sekali pakai yang telah dicelupkan pada alkohol $70 \%$. Kemudian telur segar yang telah dibersihkan dimasukan ke dalam alat DBD UV plasma. Alat DBD UV plasma dihidupkan kemudian dilakukan pretreatment dengan cara menghidupkan lampu UV selama 10 menit, fungsinya agar tidak terjadi kontaminasi. Selanjutnya sampel telur dimasukkan ke dalam ruang plasma. Diatur tegangan masukan sebesar 22 volt dan waktu selama 5 menit. Setelah telur di sterilisasi selanjutnya dilakukan pengujian.

Pengujian pada telur dilakukan pada hari ke $0,5,7,11$ dan 14 diamati secara fisik dan kimia pada sampel telur 
ayam. Tahap pengujian dilakukan pada sampel telur ayam tanpa perlakuan (a) dan telur ayam dengan perlakuan (b) yang meliputi uji fisik dan kimia. Dimana uji fisik berupa haugh unit (HU) serta indeks kuning telur (IKT). Serta uji kimia berupa $\mathrm{pH}$ kuning, $\mathrm{pH}$ putih telur serta kandungan proksimat (protein, lemak, air, abu dan kabohidrat) dari telur.

i) Haugh Unit (Wan et al., 2017)

Diamati dengan pengukuran tinggi putih telur dan kuning telur yang dilakukan dengan memecah telur dengan hati-hati pada permukaan kaca datar. Selanjutnya segera diukur menggunakan penggaris, untuk perhitungan haugh unit, diukur tinggi putih telur dan bobot telur dengan menggunakan timbangan. Persamaan untuk nilai $\mathrm{HU}$ adalah sebagai berikut:

$\mathrm{HU}=100 \log (\mathrm{H}+7,57-1,7 \mathrm{~W} 0,37)$

Keterangan: $\mathrm{H}=$ tinggi albumen $(\mathrm{mm})$

$\mathrm{W}=$ berat telur (gram)

$\mathrm{HU}=$ haugh unit

ii) Indeks Kuning Telur (Lestari, 2016)

Komponen yang digunakan untuk mengukur indeks kuning telur adalah tinggi kuning telur dan diameter kuning telur. Nilai yang diperoleh dimasukkan dalam formulasi sebagai berikut:

IKT $=$ Tinggi kuning telur $(\mathrm{mm})$ Diameter kuning telur $(\mathrm{mm})$

iii) Pengukuran $\mathrm{pH}$ (Eke, 2013)

$\mathrm{pH}$ kuning dan putih telur diukur dengan menggunakan $\mathrm{pH}$ meter (Hanna). Sekitar 2 gram sampel di homogenisasi pada $20 \mathrm{ml}$ akuades. Kemudian $\mathrm{pH}$ meter distandarisasi dengan menggunakan buffer $\mathrm{pH} 4$ dan 9. Lalu, $\mathrm{pH}$ meter dibilas dengan akuades, dan dicelupkan ke dalam sampel yang telah dihomogenisasi sebelumnya untuk menstabilkan sebelum digunakan.

\begin{tabular}{ccr}
\multicolumn{1}{c}{ Data } & yang telah & diperoleh \\
kemudian & dilakukan & analisa \\
menggunakan & metode & ANOVA
\end{tabular}

(Wackerley et al., 2008). Apabila terdapat perbedaan diuji lebih lanjut dengan menggunakan uji Tukey. Semua analisis dengan data dilakukan dengan program minitab 17.

\section{Hasil dan Pembahasan}

\section{Pengaruh DBD UV Plasma terhadap Haugh Unit Telur}

Nilai Hangh Unit (HU)

merupakan salah satu indikator kesegaran dari telur yang secara konsisten akan menurun dengan semakin meningkatnya umur induk ayam (Chang-Ho et al., 2014). Nilai HU bervariasi antara $20-110$ dan telur berkualitas baik memiliki nilai HU antara 50-100 (Yuwanta, 2010). Nilai HU berdasarkan korelasi antara bobot telur dan tinggi putih telur (Sihombing et al., 2014). Semakin kecil nilai HU maka semakin encer putih telur sehingga kualitas putih telur semakin rendah.

Semakin lama penyimpanan menunjukkan penurunan nilai Haugh Unit pada telur segar (Gambar 1). Hal ini dikarenakan pengenceran putih telur yang diakibatkan penguapan gas $\mathrm{CO}_{2}$ sehingga $\mathrm{pH}$ naik dan mempercepat pemecahan ovomucin. Hal ini sesuai dengan pendapat Widyantara et al. (2017), yang menyatakan bahwa pengenceran bagian putih telur disebabkan oleh adanya kerusakan fisikokimia dari serabut ovomucin. Penguapan $\mathrm{CO}_{2}$ disebabkan adanya penguraian senyawa $\mathrm{NaHCO}_{3}$ dari dalam telur ayam ras menjadi $\mathrm{NaOH}$ dan $\mathrm{CO}_{2} \cdot \mathrm{NaOH}$ yang dibentuk akan diurai menjadi $\mathrm{Na}^{+}$dan $\mathrm{OH}$ sedangkan $\mathrm{CO}_{2}$ yang dibentuk akan menguap, sehingga kualitas putih telur mengalami penurunan (Fahrullah, 2012). Rata-rata nilai HU selama penelitian berkisar antara 50-80, lebih tinggi jika dibandingkan dengan hasil penelitian Nova (2014) yang menunjukkan nilai HU berkisar antara 40-80. 


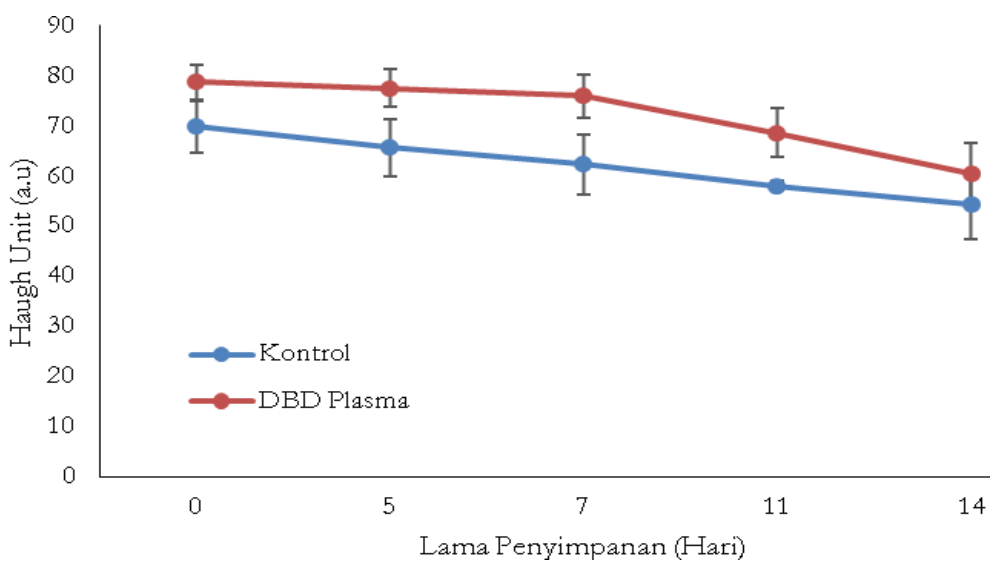

Gambar 1. Pengaruh Lama Penyimpanan Telur terhadap Nilai Haugh Unit

Aplikasi teknologi DBD UV plasma dapat mempertahankan nilai Haugh Unit dibandingkan dengan telur kontrol. Hal ini disebabkan, DBD UV Plasma dapat mempengaruhi penguapan dari $\mathrm{CO}_{2}$. Perlakuan DBD UV Plasma tidak mempengaruhi indeks kuning telur, namun dapat menyebabkan hilangnya kualitas putih telur terkait dengan penurunan Haugh Unit (Wong et al., 2003). Menurut Chen et al., (2014) bahwa DBD UV Plasma dapat menyebabkan pecahnya kantung dan kehilangan albumin atau penipisan albumen. Peningkatan hidroklorida bebas $(\mathrm{SH})$ menyebabkan denaturasi protein selama penyimpanan (Wong et al., 2003). Tidak ada perbedaan yang signifikan $(\mathrm{p}>0,05)$ yang diamati pada parameter yang dianalisis. Nilai haugh unit pad telur kontrol dan dengan telur perlakuan DBD UV plasma tidak berbeda jauh. Hal ini menunjukkan bahwa perlakuan DBD UV plasma menunjukkan tidak ada perbedaan yang signifikan dalam tingkat penguapan atau pelepasan $\mathrm{CO}_{2}$ dari albumen setelah perlakuan plasma (Caner, 2005). Chen et al., (2014) juga menunjukkan bahwa tidak ada perbedaan yang signifikan antara telur perlakuan dan tanpa perlakuan dalam parameter seperti Haugh Unit.

\section{Pengaruh DBD UV Plasma terhadap Indeks KuningTelur (IKT)}

Indeks kuning telur (IKT) adalah perbandingan tinggi kuning telur dengan garis tengahnya. Indeks kuning telur berkualitas baik berkisar antara 0.33 dan 0.50 dengan nilai rata-rata 0.42 (Barutu, 2016). Faktor yang memengaruhi indeks kuning telur antara lain lama penyimpanan, suhu dan tempat penyimpanan, kualitas membran vitelin, dan nutrisi pakan (Agro et al., 2013). Indeks kuning telur (IKT) pada kontrol maupun pada DBD UV Plasma seperti pada Gambar 2, semakin hari semakin menurun. Soeparno et al. (2011) menyatakan bahwa penyimpanan telur menyebabkan terjadinya pemindahan air dari putih telur menuju kuning telur sebanyak $10 \mathrm{mg} /$ hari pada suhu $10^{\circ} \mathrm{C}$. Tekanan osmotik kuning telur lebih besar dari putih telur sehingga air dari putih telur berpindah menuju kuning telur. Perpindahan air secara terus menerus akan menyebabkan viskositas kuning telur menurun sehingga kuning 


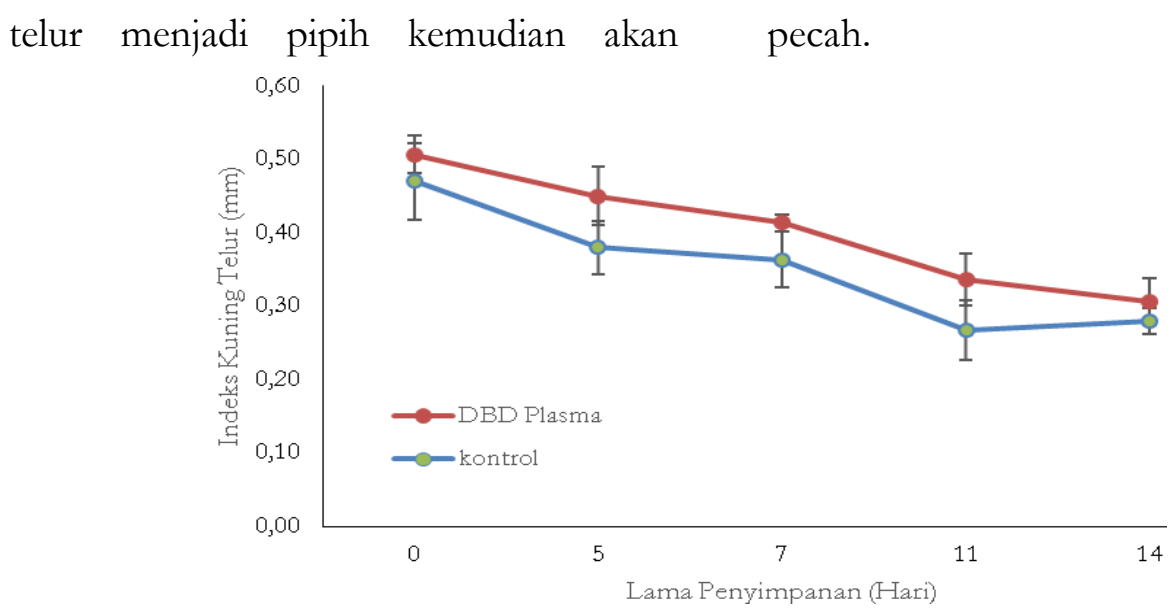

Gambar 2. Pengaruh Lama Penyimpanan (hari) terhadap Indeks Kuning Telur

Apabila dibandingkan dengan Purwati et al. (2015) yang menyatakan bahwa indeks kuning telur pada saat telur dikeluarkan adalah 0,45 , kemudian akan menurun menjadi 0,30 apabila telur disimpan selama 25 hari $\left(25^{\circ} \mathrm{C}\right)$ pada penelitian ini, nilai IKT lebih tinggi. Nilai Indeks Kuning Telur (IKT) pada telur yang diberi perlakuan DBD UV plasma lebih tinggi dibandingkan dengan kontrol (Gambar 2). Menurut Chen et al. (2014), jika chalazae menutupi kuning telur atau albumen akan menutupi kuning telur hingga tebal, serta warna kuning telur tidak akan sesuai. Karotenoid adalah pigmen alami kuning telur, yang memberikannya warna oranye terang sampai gelap (Anton, 2007). Kekurangan suplai protein akan mengakibatkan kuning telur memiliki tingkat kekuatan yang rendah. Kondisi tersebut mengakibatkan nilai indeks kuning telur yang dihasilkan juga rendah (Pribadi et al., 2015).

Tidak ada perbedaan yang signifikan $(p>0,05)$ pada warna kuning telur yang diamati setelah perlakuan DBD UV plasma maupun dengan kontrol. Menurut Wong et al. (2003), perlakuan DBD UV Plasma tidak mempengaruhi indeks kuning telur, namun pada parameter lain dapat mempengaruhi. Dalam penelitian Chen et al. (2014), tidak ada perbedaan yang signifikan terhadap telur dengan perlakuan DBD UV Plasma dan kontrol. Pada penelitian ini, perbedaan antara kontrol dengan pelakuan DBD UV Plasma.

\section{Pengaruh DBD UV Plasma terhadap pH Telur}

Potensial of Hydrogen $(\mathrm{pH})$ putih telur dengan kualitas yang baik nilainya sekitar 7.0. Selama penyimpanan $\mathrm{pH}$ telur akan naik. Nilai $\mathrm{pH}$ kuning telur juga meningkat namun tidak setinggi kenaikan $\mathrm{pH}$ putih telur. Nilai $\mathrm{pH}$ kuning telur dengan kualitas baik adalah 6.0 (Barutu, 2016). Semakin lama penyimpanan menunjukan adanya kenaikan nilai $\mathrm{pH}$ putih dan kuning pada telur segar. Hal ini dikarenakan, $\mathrm{CO}_{2}$ yang hilang melalui pori kerabang telur mengakibatkan konsentrasi ion bikarbonat dalam putih telur menurun dan merusak sistem buffer. Hal tersebut menjadikan $\mathrm{pH}$ naik dan putih telur bersifat basa yang diikuti dengan kerusakan serabut serabut ovomucin (yang memberikan tekstur kental), sehingga kekentalan putih telur menurun. Putih telur yang mempunyai $\mathrm{pH}$ meningkat menjadi basa selain 
disebabkan oleh menguapnya $\mathrm{CO}_{2}$, juga disebabkan karena putih telur dibagian yang kental mengalami pengenceran yang akhirnya akan merembes ke kuning telur. Agustina et al. (2013) menjelaskan pengenceran putih telur disebabkan karena pecahnya serabut mucin yang mengakibatkan meningkatnya $\mathrm{pH}$ putih telur.

Begitupun, dengan $\mathrm{pH}$ kuning telur terus mengalami kenaikan. Hal ini disebabkan karena, penguapan $\mathrm{CO}_{2}$ yang tinggi dapat meningkatkan derajat keasaman putih dan kuning telur. Dalam hal ini, penguapan $\mathrm{CO}_{2}$ menyebabkan sistem buffer pada putih telur menurun sehingga terjadi pengenceran putih telur dan perembesan $\mathrm{H}_{2} \mathrm{O}$ dari putih telur ke kuning telur. Perpindahan $\mathrm{H}_{2} \mathrm{O}$ dari putih telur ke kuning telur dapat menyebabkan berat kuning telur meningkat dan peregangan membran vitelin sehingga terjadi percampuran antara putih telur dan kuning telur yang menyebabkan peningkatan $\mathrm{pH}$ kuning telur (Soekarto, 2013). Menurut Lestari et al. (2015), perembesan $\mathrm{H}_{2} \mathrm{O}$ dapat menyebabkan peregangan dan pecahnya membran vitelin sehingga terjadi percampuran putih dan kuning telur serta mengakibatkan peningkatan $\mathrm{pH}$.

Menurut Belitz et al. (2009), pH putih telur yang baru dikeluarkan atau telur segar kira-kira 7,6-7,9 sedangkan dalam penelitian pada kontrol sekitar lebih dari 7.5. Kemudian terus meningkat sampai hari ke-14 penyimpanan menjadi lebih basa. $\mathrm{pH}$ meningkat sampai nilai maksimal 9,7 tergantung temperatur dan lama penyimpanan. Nilai $\mathrm{pH}$ kuning telur segar mendekati 6.0, sedangkan dalam penelitian ini baik pada kontrol maupun pada perlakuan DBD UV plasma, nilainya mendekati 6.0 (Chen et al., 2014). Kemudian terus meningkat pada penyimpanan hari ke-14. Selama penyimpanan $\mathrm{pH}$ telur akan naik. Nilai $\mathrm{pH}$ kuning telur juga meningkat namun tidak setinggi kenaikan $\mathrm{pH}$ putih telur. Nilai $\mathrm{pH}$ kuning telur dengan kualitas baik adalah 6.0. Kenaikan $\mathrm{pH}$ telur menyebabkan protein isi telur rentan terhadap enzim proteolitik dari telur dan mempercepat proses perubahan putih telur menjadi encer (Soekarto 2013).

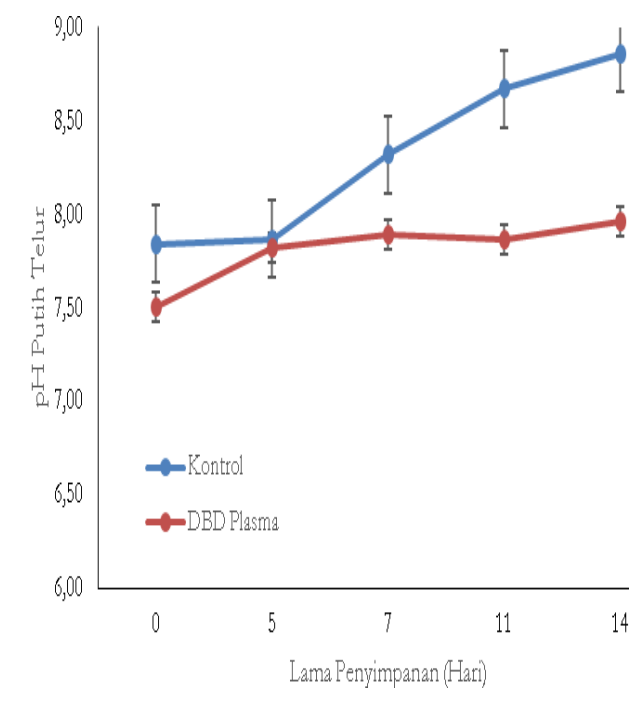

(a)

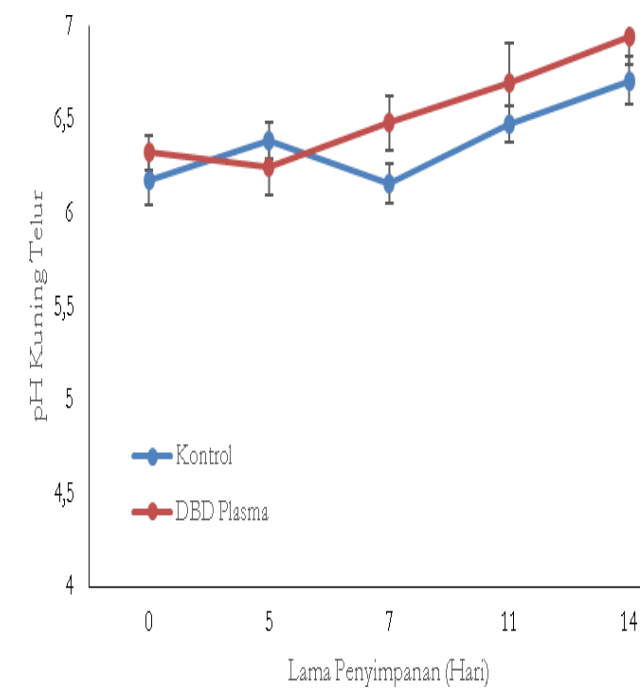

(b)

Gambar 3. Pengaruh Lama Penyimpanan terhadap pH Putih Telur (a) dan Kuning Telur (b) 
Aplikasi teknologi DBD UV plasma dapat mempertahankan nilai $\mathrm{pH}$ putih dan telur ayam dibandingkan dengan kontrol. Berdasarkan Chen et al. (2014), pH putih telur terus meningkat dari hari ke 0 sampai hari ke 42. Hal ini dimungkinkan terjadi karena perbedaan pada telur ayam yang digunakan. $\mathrm{pH}$ putih telur yang diolah tetap pada tingkat yang sama sepanjang penyimpanan 42 hari. Dalam penelitiannya, telur disimpan pada kemasan dengan kandungan $\mathrm{CO}_{2}$ tinggi, kemudian sejumlah $\mathrm{CO}_{2}$ terpenetrasi dalam putih telur. Oleh karena itu, $\mathrm{pH}$ rata-rata untuk putih telur tetap konstan sekitar $\mathrm{pH} \quad 7,5$ selama periode penyimpanan 42 hari. Dalam telur yang baru diletakkan, $\mathrm{pH}$ albumen adalah antara 7,6 dan 8.5. $\mathrm{pH}$ putih telur meningkat dari 8,64 menjadi 9,25 untuk telur yang disimpan selama 12 minggu di suhu ruang (Biladeau et al., 2009). Menurut Chen et al. (2014), ada sedikit perubahan $\mathrm{pH}$ kuning telur untuk kedua telur yang diberi perlakuan DBD UV Plasma dan tidak diberi perlakuan selama penyimpanan refrigerasi 42 hari. Telur yang disimpan pada suhu ruang dalam penelitian Biladeau et al. (2009), rata-rata $\mathrm{pH}$ kuning telur meningkat menjadi $\mathrm{pH}$ 6,28 pada minggu ke 6, dan $\mathrm{pH}$ 6,18 pada hari ke 42 dalam penelitiannya. $\mathrm{pH}$ kuning telur pada penyimpanan suhu ruang yang tidak diberi perlakuan dan diberi perlakuan DBD UV Plasma tidak menunjukkan perubahan signifikan selama 42 hari. $\mathrm{pH}$ kuning telur pada umumnya mendekati 6,0 (Wan et al., 2017). Selama penyimpanan, $\mathrm{pH}$ kuning telur akan meningkat secara bertahap hingga mencapai 6,4-6,9.

Perbedaan $\mathrm{pH}$ putih dan kuning telur pada telur pada kontrol dan perlakuan DBD UV Plasma tidak berbeda jauh. Tidak ada perubahan signifikan $(\mathrm{p}>0,05)$ pada $\mathrm{pH}$ putih telur untuk kontrol maupun dengan perlakuan DBD UV plasma yang diamati setelah perlakuan penyimpanan selama 14 hari. Tidak ada perubahan kekuatan membran vitelline yang diamati setelah perlakuan DBD UV Plasma dan hasilnya sebanding dengan nilai yang dipublikasikan sebelumnya (Banerjee, 2010).

\section{Pengaruh DBD UV Plasma terhadap Kandungan Nutrisi Telur}

Analisis ini penting untuk mengetahui komposisi gizi pada telur ayam ras yang disterilisasi menggunakan alat berbasis Dielectric Barrier Discharge (DBD) UV plasma. Telur yang diujikan adalah telur tanpa perlakuan sterilisasi dan telur yang disterilisasi menggunakan tegangan sebesar $22 \mathrm{~V}$ selama 5 menit. Hasil dari pengujian nutrisi telur dapat dilihat pada Tabel 7.

Tabel 7. Hasil Pengujian Proksimat Penyimpanan Awal dan Akhir Penyimpanan Telur $65 \mathrm{gr}(\mathrm{b} / \mathrm{v})$

\begin{tabular}{ccccc}
\hline \multirow{2}{*}{ Parameter } & Hari ke- & \multicolumn{2}{c}{ Perlakuan } & $\begin{array}{c}\text { Standar Telur dalam 65 gr } \\
\text { (SNI 3926:2008) }\end{array}$ \\
\cline { 2 - 4 } Protein (\%) & Hari ke-0 & 7.13 & 7.84 & $8.00-13.40$ \\
& Hari ke-14 & 11.81 & 10.81 & \\
Lemak (\%) & Hari ke-0 & 8.38 & 7.3 & $8.5-11.80$ \\
& Hari ke-14 & 8.43 & 7.26 & \\
Air (\%) & Hari ke-0 & 77.75 & 80.58 & $72.5-75.5$ \\
& Hari ke-14 & 74.41 & 77.5 & $0.80-1.00$ \\
Abu (\%) & Hari ke-0 & 0.89 & 0.78 & \\
& Hari ke-14 & 0.87 & 0.84 & \\
\hline
\end{tabular}


E. Widyastuti dan A. Daydeva/ Buana Sains Vol 18 No 1 : 85-96

Kandungan protein pada telur
kontrol makin meningkat setelah
penyimpanan 14 hari. Yuwanta (2010)
menjelaskan bahwa ovalbumin adalah
protein utama dari putih telur yang
menempati $54 \%$ total protein putih telur,
ovalbumin ini mudah terpecah oleh
adanya panas sehingga terjadi koagulasi
dan kehilangan air dapat terjadi karena
lama penyimpanan telur, penguapan air
mengakibatkan pula terjadinya perluasan
rongga udara. Hasil kandungan protein
makin meningkat setelah diberi perlakuan DBD UV Plasma. Berdasar Ji et al. (2017), perlakuan DBD UV Plasma mempengaruhi terhadap kelarutan, stabilitas emulsi, dan protein. Efek DBD UV Plasma dalam protein dipelajari pada ikan makarel segar, dimana menghasilkan penurunan di dalam air yang terletak di jaringan myofibrillar yang padat protein. Kandungan lemak meningkat pada hari ke-14 pada telur kontrol. Seharusnya, semakin lama penyimpanan kandungan lemak telur semakin menurun. Menurut Alfiah et al. (2015) salah satu penyebab kerusakan lemak adalah adanya reaksi hidrolisis. Jika kadar air didalam lemak tersebut tinggi, maka kemungkinan terjadinya reaksi hidrolisis akan semakin besar dan akan memicu kenaikan asam lemak bebas sebagai hasil pemecahan trigliserida. Kadar lemak pada telur ayam dengan perlakuan DBD UV Plasma mengalami penurunan. Rusdi (2002), yang mengatakan bahwa DBD UV Plasma dapat mempertahankan kadar lemak. DBD UV plasma yang kontak dengan bahan, dapat mempertahankan kadar lemak yang paling tinggi. Hal ini dapat dijelaskan sebagai berikut bahwa makin lama DBD UV Plasma kontak dengan bahan dan makin rendah suhu bahan maka makin banyak konsentrasi yang terlarut dalam bahan dan kesempatan untuk memisahkan ikatan lemak dengan protein yang berada dalam bahan tersebut makin banyak.

Kandungan air makin menurun pada hari ke-14 pada telur kontrol. Sudaryani (2003) menyatakan bahwa kadar air merupakan komposisi telur yang penting karena mempengaruhi kualitas interior telur dan selama penyimpanan, kadar air putih telur menurun tidak hanya disebabkan penguapan air tetapi juga adanya difusi air dari putih telur menuju kuning telur. Kadar air telur dipengaruhi oleh kecepatan penguapan, suhu dan kelembaban tempat penyimpanan telur. Penggunaan DBD UV Plasma semakin membuat menurun kadar air sesuai penyimpanan. Saraslifah (2016), dimana penggunaan DBD UV Plasma semakin membuat menurun kadar air sesuai penyimpanan. Ditunjukkan bahwa semakin lama penyimpanan yakni mulai penyimpanan sampai hari ke-35 kadar air bahan mengalami penurunan. Karena elektron yang dihasilkan oleh DBD UV Plasma akan berenergi dan menyalurkannya pada molekul dalam bahan. Kemudian terjadi proses transfer energi elektron yang akan menyebabkan kadar air pada telur akan menurun pada hari ke-14. Kadar abu menurun pada hari ke-14 pada telur kontrol. Pada penelitian Gumay (2009) tentang nilai gizi pada telur asin, menunjukkan bahwa kadar abu mengalami peningkatan karena dipengaruhi faktor pakan yang diberikan kepada itik. Serta dipengaruhi pula oleh proses pembuatan dari telur asin itu sendiri. Bila dibandingkan dengan telur itik segar, telur yang melalui pemrosesan lebih meningkat kadar abunya. Kadar abu pada telur dengan perlakuan DBD UV Plasma mengalami peningkatan pada hari ke 14. Pengaruh teknologi plasma pada perubahan kimia pada makanan belum diketahui secara pasti, namun ada peningkatan kadar flavanoid pada 
perlakuan plasma menggunakan selada domba, dikarenakan pengikisan kulit ari pada bahan (Eisenbrand, 2012). Belum diketahui secara pasti alasan perubahan kimia dalam proses sterilisasi telur dengan menggunakan teknologi plasma (Pradeep, 2016).

\section{Kesimpulan}

Aplikasi Dielectric barrier discharge UV plasma (DBD UV plasma) dapat mempertahan kualitas fisik (Haugh Unit dan Indeks Kuning Telur) dan kimia (pH putih telur, $\mathrm{pH}$ kuning telur dan kandungan nutrisi) pada telur ayam (Gallus gallus domesticus) dibandingkan dengan kontrol. Pada kandungan nutrisi, aplikasi DBD UV plasma pada telur ayam (Gallus gallus domesticus) tidak memberikan perbedaan yang signifikan.

\section{Daftar Pustaka}

Agustina, N., Thohari, I., dan Rosyidi, D. 2013. Evaluasi Sifat Putih Telur Ayam Pasteurisasi Ditinjau dari pH, Kadar Air, Sifat Emulsi dan Daya Kembang Angel Cake. Jurnal Ilmu-Ilmu Peternakan 23, 6-13.

Alfiah, C., Wahono H. S. 2015. Penanganan Pasca Panen Kelapa Sawit (Penyemprotan $\mathrm{CaCl}_{2}$ Dan Kalium Sorbat Terhadap Mutu Crude Palm Oil). Jurnal Pangan dan Agroindustri 3, 61-72.

Anggraeni, E. T., Sumarsono, F., Hayuningsih, H. P., Mashitoh, D., Daydeva, A., dan Widyastuti, E. 2017. Effect of Nano Dielectric Barrier Discharge Plasma Treatment on Salmonela Inactivation in Chicken Eggs. Proceedings $1^{\text {st }}$ Young Scientist International Seminar, hal 302305, Universitas Brawijaya, Malang, 13 Juli 2017.
Anton, M. 2007. Composition and Structure of Hen Egg Yolk. In Bioactive Egg Compounds. R. Huopalahti, R. López-Fandiño, M. Anton, and R. Schade (eds). Springer Berlin Heidelberg, Jerman.

Banerjee, P. 2010. The effect of carbon dioxide on lysozyme activity and quality of chicken eggs. Thesis, Purdue University, West Lafayette.

Barutu, E. M. S. 2016. Kualitas dan Masa Simpan Telur Ayam Konsumsi pada Suhu Ruang. Skripsi, IPB, Bogor.

Belitz, H. D and W. Grosch. 2009. Food chemistry. Edisi 4 Revisi. Berlin.

Biladeau, A dan Keener, K. 2009. The Effects of Edible Coating on Chicken Egg Quality Under Refrigerated Storage. Poutry Science 88, 1266-1274.

Caner, C. 2005. The effect of edible eggshell coatings on egg quality and consumer perception. Journal of the Science of Food and Agriculture 85, 1897-1902.

Chang-Ho K, Jong-Ho S, Jae-Cheong L. Kyung-Woo L. 2014. Age-related changes in egg quality of hy-line brown hens. IJPS 13, 510-514.

Chen, Y. 2014. High Voltage Atmospheric Cold Plasma Treatment Of Refrigerated Chicken Eggs For Control Of Salmonella Enteritidis On External Surfaces. Thesis, Purdue University, West Lafayette.

Cui, H, Cuixia M., Changzhu L., and Lin. 2016. Enhancing The Antibacterial Activity of Thyme Oil Against Salmonella on Eggshell by Plasma-Assited Process. Journal Of Food Control 70, 183-19. 
Eisenbrand, G., Diel, P., Engel, K. H., Gremmels, J., Hengstler, J.G., Hans-Ulrich H., \HansGeorg J., Knorr, D., Marko, D., Rietjens, I., Steinberg, P. 2012. Opinion on The Use of Plasma Processes for Treatment of Foods. Jerman: SKLM Commission Secretariat.

Eke, M. O., Olaitan, N. I., dan Ochefu, J. H. 2013. Effect of Storage Conditions on the Quality Attributes of Shell (Table) Eggs. Nigerian Food Journal 31, 18-24.

Fahruhllah. 2012. Pengaruh Penggunaan Probiotik Komersial sebagai Bahan Curing pada Pembuatan Telur Itik Asin. Program Studi Ilmu dan Teknologi Pangan Jurusan Teknologi Pertanian. Skripsi, Universitas Hasanuddin, Makassar.

Haryoto. 2010. Membuat Telur Asin. Kanisius, Yogyakarta.

Ji, H., Dong, S., dan Han, F. 2017. Effects of Dielectric Barrier Discharge (DBD) Cold Plasma Treatment on Physicochemical and Functional Properties of Peanut Protein. Food and Bioprocess Technology 11, 344354.

Kalfat, A. J. J. dan Zubaidah, E. 2015. Iradiasi Sinar Gamma pada Telur Ayam Broiler sebagai Upaya Peningkatan Keamanan Pangan (Kajian Dosis Iradiasi dan Penyimpanan Suhu $4^{\circ} \mathrm{C}$ ). Jural Pangan dan Agroindustri 3, 14381445.

Koswara, S. 2009. Teknologi Pengolahan Telur. Universitas Muhammadiah Semarang, Semarang.

Lestari, D, Riyanti dan Wanniatie, V. 2015. Pengaruh Lama Penyimpanan dan Warna Kerabang terhadap Kualitas Internal Telur Itik Tegal. Jurnal
Ilmiah Peternakan Terpadu 3, 7 14.

Litbang Pertanian. 2010. Telur Sumber Makanan Bergizi. Jakarta: Kementrian Pertanian Republik Indonesia.

Morgan, R. 2009. UV “Green” Light Desinfection. Dairy Industry. Intl. 54, 33-35.

Muchtadi, T. R, Ayustaningwarno, F dan Sugiyono. 2010. Ilmu Pengetahuan Bahan Pangan. Penerbit Alfabeta, Bandung.

Nova, I., Kurrtini, T., Wanniatie, V. Pengaruh Lama Penyimpanan terhadap Kualitas Internal Telur Ayam Ras pada Fase Produksi Pertama. Jurnal Ilmiah Peternakan 2.

Nur, M. 2011. Fisika Plasma dan Aplikasinya. Universitas Diponegoro, Semarang.

Nuryati, L,. B. Waryanto, Noviati. 2015. (Outlook Telur) Komoditas Pertanian Sub Sektor Peternakan. Pusat Data dan Sistem Informasi Pertanian. Jakarta Pemerintah RI. 1996. UU RI No. 7 Tahun 1996 Tentang Pangan. Jakarta: Lembaran Negara RI.

Pratama, Y., Adianti, A., dan Prastiwi D. .2016. Penerapan Teknologi Plasma dengan Memanfaatkan Rancang Bangun Ozone Generator untuk Pengawetan Cabai Merah (Capsicum Annum L.) Guna Mendukung Ketahanan Pangan Nasional. Youngster Physics Journal. Volume 5, 69-74.

Pribadi A, Kurtini T, Sumardi. 2015. Pengaruh Pemberian Probiotik dari Mikroba Lokal terhadap Kualitas Indeks Albumen, Indeks Yolk, dan Warna Yolk pada Umur Telur 10 Hari. Jurnal Ilmiah Peternakan Terpadu. Volume 3, 180-184. 
E. Widyastuti dan A. Daydeva/ Buana Sains Vol 18 No 1 : 85-96

Purwati, D., Djaelani M., dan Yuniwarti E. Indeks kuning Telur (IKT), Haugh Unit (HU) dan Bobot Telur pada Berbagai Itik Lokal di Jawa Tengah. Jurnal Biologi. Vol. 4.

Rijal, S., dan Nur, M. 2016. Analisa Pengaruh Ozonisasi Hasil Lucutan Plasma Berpenghalang Dielektrik pada Beras terhadap Perubahan Amilografi, Kekerasan dan Warna. Youngster Physics Journal. Volume: 4, 61-66.

Rusdi, U. dan Suliasih, N. 2002. Ozonisasi dan Kualitas Air Susu. Jurnal Bionatura 4, 96-107.

Saraslifah, Nur, M., dan Arianto, F. 2016. Pengaruh Ozon yang Dibangkitkan Melalui Reaktor Plasma Berpenghalang Dielektrik Elektroda Silinder Spiral Terhadap Pengawetan Cabai. Youngster Physics Journal 5.

Saraswati, D. 2012. Uji Bakteri Salmonella $s p$ pada Telur Bebek, Telur Puyuh, dan Telur Ayam Kampungf yang Diperdagangkan di Pasar Liluwo Kota Gorontalo. Skripsi, Universitas Negeri Gorontalo, Gorontalo.

Sihombing R, Kurtini T, Nova K. 2014.

Pengaruh lama penyimpanan terhadap Kualitas Internal Telur Ayam Ras pada Fase Kedua. Jurnal Ilmiah Peternakan Terpadu. Volume 2, 81-86.

Soekarto, S. 2013. Teknologi Penanganan dan Pengolahan Telur. Alfabeta, Bandung.

Soeparno, R.A., Rihastuti, I., dan S. Triatmojo. 2011. Dasar Teknologi Hasil Ternak. Gadjah Mada University Press, Yogyakarta.

Sudarti. 2016. Utilization of Extremely Low Frequency (ELF) Magnetic Field is as Alternative
Sterilization of Salmonella Typhimurium in Gado-Gado. Journal of Agriculture and Agricultural Science Procedia 9.

Teke, S., Nur, M., dan Winarni, T. A. 2014. Produksi Ozon dalam Reaktor Dielectric Barrier Discharge Plasma (DBDP) Terkait Panjang Reaktor dan Laju Alir Udara serta Pemanfaatannya untuk Menjaga Kualitas Asam Amino Ikan. Jurnal Berkala Fisika 17, 25-32.

Wackerley, D.D., Mendenhall, W., Scheaffer, R. L. 2008. Mathematical statistics with applications, Thompson Brooks/Cole, USA.

Wan, Z., Chen, Y., Pankaj, S. K., dan Keener, K. M. 2017. High Voltage Atmospheric Cold Plasma Treatment of Refrigerated Chicken Egss for Control of Salmonella enteritidis Contamination on Egg Shell. Food Science and Technology 76, 124-130.

Warintek. 2016. 8 Pengawetan Telur Segar. Tekno Pangan dan Agroindustri, Volume 1 Nomor 2.

Widyastuti, E, Sumarsono, F., Anggraeni, E. T., Hayuningsih, H. P., Mashitoh, D., dan Daydeva, A.. 2017. Modern Sterilization Machine Rancang Bangun Mesin Sterilisasi Telur Ayam Berbasis Dielectric Barrier Discharge-UV Plasma. Prosiding Simposium Nasional "Contribute Youth Innovation To Be Part of Magnificent Journey for SDG's 2030", hal 264-270, Fakultas Teknologi Pertanian, Universitas Brawijaya 17 Mei 2017.

Wong, P dan Kitts, D. 2003. Physiochemical and Functional Properties of Shell Eggs 
Following Electron Beam

Irradiation. Journal of the Science of Food and Agriculture $83,44-52$.

Yuwanta T. 2010. Telur dan Kualitas Telur. Gadjah Mada University Pr, Yogyakarta. 